Manuela Ingaldi ${ }^{l}$

\title{
WYKORZYSTANIE ANALIZY SWOT DO OKREŚLENIA POZYCJI STRATEGICZNEJ PRZEDSIĘBIORSTWA POLIGRAFICZNEGO
}

\begin{abstract}
Streszczenie: W artykule wykorzystano analizę SWOT do określenia pozycji strategicznej wybranego przedsiębiorstwa poligraficznego. Opisano krótko metodologię badań oraz scharakteryzowano wybrane przedsiębiorstwo. W wyniku przeprowadzonej analizy SWOT określono rodzaj strategii adekwatnej do sytuacji badanego przedsiębiorstwa. Okazało się, że dla badanego przedsiębiorstwa poligraficznego adekwatną strategią jest strategia maxi-maxi, czyli strategię agresywną. W przedsiębiorstwie przeważają mocne strony oraz możliwości (choć te drugie z mniejszym stopniu). Na tej podstawie wskazano, w jaki sposób wykorzystać możliwości, aby wykorzystać lub poprawić mocne strony przedsiębiorstwa.
\end{abstract}

Słowa kluczowe: SWOT, strategia, pozycja strategiczna, zarządzanie

\section{Wstęp}

W obecnych czasach każde przedsiębiorstwo funkcjonuje w środowisku, które ulega ciągłym zmianom. Proces, który analizuje te zmiany i modyfikuje sposób działania i reagowania przedsiębiorstwa jest nazywany strategią.

W literaturze odstępnych jest bardzo wiele różnych definicji strategii. Jednak wszystkie te definicje oparte są na starych definicjach. Według Chandlera strategia to określenie podstawowych długoterminowych celów przedsiębiorstwa, a także przyjęcie kierunków działań i alokacja zasobów niezbędnych do osiągnięcia tych celów (CHANDLER A. A., JR. 1962).

Podobną definicja została stworzona przez naukowców Learned, Christensen, Andrews oraz Guth. Według nich strategia to wzór celów, powodów oraz główna polityka i plany osiągnięcia tych celów, stwierdzone w taki sposób, aby określić, w jakim stanie jest przedsiębiorstwa i w jakim powinno być (LEARNED E. P., CHRISTENSEN C. P., ANDREWS K. R., GUTH W. D. 1965).

H. Mintzberg zaproponował nowatorski sposób patrzenia na strategie. Jego koncepcja zakłada wzięcie pod uwagę i wykorzystanie wszystkich 5 elementów rozpoczynających się na literę P (MINTZBERG H.1979):

\footnotetext{
${ }^{1}$ Dr inż., Politechnika Częstochowska, Wydział Zarządzania, Katedra Inżynierii Produkcji i Bezpieczeństwa
} 
- plan - planowanie jest pierwszym jednym z najważniejszych elementów każdej strategii,

- pattern - wzorce według których przedsiębiorstwo powinno postępować, aby osiągnąć zamierzone cele,

- ploy - rozumiane jako taktyka działania przedsiębiorstwa poprzez uzyskiwanie przewagi konkurencyjnej,

- position - określenie miejsca w obecnym otoczeniu konkurencyjnym,

- perspective - perspektywa patrzenia na przyszłość.

Budowa strategii jest poszukiwaniem syntez, ale nie da się stworzyć porządnej strategii firmy bez rzetelnej analizy danych o otoczeniu i firmie. Jednym z użytecznych instrumentów, które mogą być wykorzystywane do budowania strategii jest analiza SWOT. Pozwala wykorzystać zgromadzone informacje do opracowania strategii działania opartej na silnych stronach i szansach, przy jednoczesnym eliminowaniu bądź ograniczaniu słabych stron i zagrożeń (KotUs M., HolOTA T., PAULIČEK T., PETRÍK M., SKLENÁR M. 2011).

Poligrafia w Polsce ma się całkiem dobrze - usługi i produkty oferowane przez polskich przedstawicieli tego sektora cieszą się rosnącą popularnością za granicą. Zainteresowanie usługami poligraficznymi jest na bardzo wysokim poziomie. W ostatnich latach rozwój trochę zwolnił, co związane jest z ogólną komputeryzacją gospodarstw domowych, w wielu domach znajdują się różnego typu drukarki. Jednak sama branże nadal brnie do przodu, a wartość sprzedaży w sektorze poligraficznym ciągle rośnie. Najlepiej na rynku powodzi się średnim, oraz dużym firmom. Cała branża poligraficzna $\mathrm{w}$ bardzo szybkim tempie stara się wprowadzać do swoich przedsiębiorstw różne rozwiązania informatyczne, które w znaczącym stopniu są $\mathrm{w}$ stanie usprawnić działania firm. Nowoczesne rozwiązania to nie tylko rozwój na rynku krajowym, ale również szansa na zaistnienie na rynkach zagranicznych dla większej ilości firm poligraficznych. Już dziś duża ich ilość posiada strony internetowe, za których pomocą możliwe jest składanie zamówień, oraz ich opłacanie (Printing Industry ... 2016).

Branża poligraficzna często pomijana jest $\mathrm{w}$ badaniach prowadzonych przez polskich naukowców, dlatego autorka podjęła się analizy wybranego przedsiębiorstwa tej branży. Artykuł stanowi pierwszy etap projektu prowadzonego przy współpracy z wybranym przedsiębiorstwem branży poligraficznej.

Celem artykułu było wykorzystanie analiz SWOT do określenia pozycji strategicznej wybranego przedsiębiorstwa poligraficznego. Opisano krótko metodologię badań oraz scharakteryzowano wybrane przedsiębiorstwo. W wyniku przeprowadzonej analizy SWOT określono rodzaj strategii adekwatnej do sytuacji badanego przedsiębiorstwa oraz wskazano możliwości działań w ujęciu tej strategii. 


\section{Metodologia}

Analiza SWOT jest jedną z najbardziej popularnych technik analitycznych. Analiza ta służy do opracowania ogólnej strategii rozwoju, a także strategii funkcjonalnych (ułamkowej), dotyczącej funkcji, jaką ma pełnić państwo, jednostka samorządu terytorialnego lub przedsiębiorstwo (marketing, finanse, logistyka itp.) (GoranczewsKi B., PuCiato D. 2010). Gierszewska i Romanowska twierdzą, że analiza SWOT nie jest metodą analizy strategicznej, ale jest "unikalnym algorytmem procesu analizy strategicznej, propozycją systemową i szeroką oceną czynników zewnętrznych i wewnętrznych, które określają obecny stan przedsiębiorstwa i jego potencjał rozwojowy" (GIERSZEwSKA G., ROMANOwSKA M. 2002). Można zatem stwierdzić, że jej głównym celem jest określenie strategii, które będą stanowić konkretny model biznesowy, który najlepiej dopasuje zasoby i możliwości organizacji do wymogów środowiska, w którym działa przedsiębiorstwo (PUSTĚJOVSKÁ P., JuRSOVÁ S., BROŽOVÁ S., PIVKO M. 2010).

Analiza SWOT może być przeprowadzona dla produktu, miejsca, przemysłu lub osoby. Obejmuje określenie celu przedsięwzięcia lub projektu oraz określenie czynników wewnętrznych i zewnętrznych, które są korzystne i niekorzystne dla osiągnięcia tego celu. Technika ta była stworzona przez Alberta Humphrey'a, który w latach sześćdziesiątych i siedemdziesiątych prowadził konwencję w Stanford Research Institute (obecnie SRI International), wykorzystując dane $\mathrm{z}$ firm Fortune 500. Przeprowadzono badania na zlecenie największych amerykańskich przedsiębiorstw, których celem było wskazanie sposobów poprawy procesów planowania strategicznego i unikania błędów w planowaniu. Stopień, w jakim środowisko wewnętrzne przedsiębiorstwa jest zgodne $\mathrm{z}$ jego otoczeniem zewnętrznym wyraża się pojęciem strategicznego dopasowania (PRUSAK R, KARDAS E., SKUZA Z. 2012).

Analiza SWOT polega na podzieleniu zebranych informacji na cztery grupy (rys. 1) (INGALDI M., JAGUSIAK-KOCIK M., ZGAiBA A. 2013.):

- S (Strengths) - mocne strony: wszystko to co stanowi atut, przewagę, zaletę. Są to więc elementy, które w sposób pozytywny wyróżniają ją w otoczeniu i spośród konkurencji, są to tzw. kluczowe czynniki sukcesu organizacji umożliwiające dostosowywanie się jej do zmieniających się uwarunkowań otoczenia rynkowego.

- W (Weaknesses) - słabe strony: wszystko to co stanowi słabość, barierę, wadę. Są one konsekwencją ograniczeń zasobów i niedostatecznych kwalifikacji pracowników i kierownictwa. Słabe strony związane są także ze wszelkimi innymi obszarami funkcjonowania, które ograniczają sprawność jej działania i reagowania na zmieniające się wymagania klientów i działania konkurencji. Obszary działalności poddawane analizie są identyczne jak przedstawione wyżej dla mocnych stron. 
- O (Opportunities) - szanse: wszystko to co stwarza szansę korzystnej zmiany. Są to wszelkie istniejące, lub przewidywane procesy, zjawiska i trendy zachodzące $\mathrm{w}$ otoczeniu organizacji, które odpowiednio wykorzystane mogą stać się impulsem do jej rozwoju oraz pomogą osłabić wpływ ewentualnych pojawiających się zagrożeń.

- T (Threats) - zagrożenia: wszystko to co stwarza niebezpieczeństwo zmiany niekorzystnej. Są to wszystkie procesy, zjawiska i trendy zachodzące w otoczeniu organizacji, które stanowią lub stanowić mogą barierę w rozwoju organizacji, utrudniają jej funkcjonowanie, podnoszą koszty działania lub mogą doprowadzić do upadku przedsiębiorstwa.

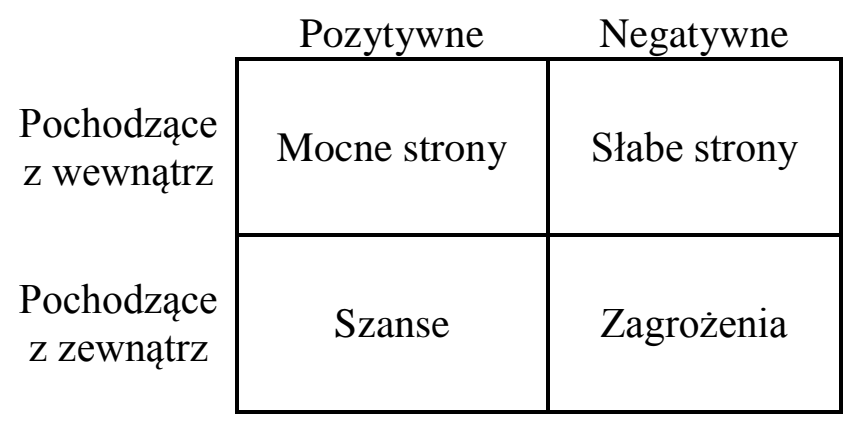

Rys. 1. Elementy analizy SWOT

Źródło: opracowanie własne na podstawie SWOT analysis. Strategy skills. Team FME, 2013

Efektem przeprowadzonej analizy SWOT jest określenie strategii dla badanego przedsiębiorstwa. Wyróżnia się cztery rodzaje strategii (GORANCZEWSKI B., PUCIATO D. 2010):

- Sytuacja SO (mocne strony-szanse) - strategia maxi-maxi (agresywna). Dotyczy to organizacji zdominowanej przez mocne strony i szanse w jej otoczeniu. W tej sytuacji na przykład mocne strony powinny być wykorzystane do wykorzystania szans $\mathrm{z}$ otoczenia, poprzez silną ekspansję rynku i próby osiągnięcia zróżnicowanego rozwoju.

- Sytuacja WO (słabe strony-szanse) - strategia mini-maxi (konkurencyjna). Odnosi się do organizacji, która jest zdominowana przez słabe strony, ale która działa w korzystnym środowisku (przewaga szans). W związku z tym strategia powinna koncentrować się na wykorzystaniu możliwości, a jednocześnie eliminowaniu słabości.

- Sytuacja ST (mocne strony-zagrożenia) - strategia maxi-mini (konserwatywna). W tej sytuacji organizacja ma duży potencjał wewnętrzny, ale działa w niekorzystnych warunkach zewnętrznych. Dlatego musi pokonać zagrożenia, w jak najlepszy sposób wykorzystując swoje mocne strony. 
- Sytuacja WT (słabe strony-zagrożenia) - strategia mini-mini (defensywna). Dotyczy to organizacji bez perspektyw rozwoju i z małym (słabym) wewnętrznym potencjałem, działającej w niekorzystnej sytuacji zewnętrznej. Jej celem jest zminimalizowanie słabości i uniknięcie zagrożeń.

W artykule w celu określenia pozycji strategicznej badanego przedsiębiorstwa poligraficznego, przeprowadzono jego analizę wewnętrzną, w której wyszczególniono mocne i słabe strony przedsiębiorstwa oraz analizę wewnętrzną, która pozwoliła określić szansę $\mathrm{i}$ zagrożenia płynące $\mathrm{z}$ otoczenia tegoż przedsiębiorstwa. Ocena poszczególnych czynników odbyła się etapami. Na początku wyszczególniono wszystkie mocne i słabe strony badanego przedsiębiorstwa oraz pojawiające się w jego otoczeniu szanse i zagrożenia. Następnie każdej grupie czynników przyznano wagi, które po podsumowaniu dały 1 . Wagi przyznawano w zależności od wpływu na branże poligraficzną. Następnie za pomocą 9 stopniowej skali oceniono czynniki w zależności od ich wpływu na badane przedsiębiorstwo. Obliczono iloczyny wag i ocen dla poszczególnych czynników oraz średnie ważone dla poszczególnych grup (KADŁUBEK M., INGALDI M. 2016).

Jak wspomniano, analiza SWOT pozwala wskazań pozycje strategiczną badanego przedsiębiorstwa oraz określić kierunki tej strategii. Pozycję tą wskazuje punkt w układzie kartezjańskim (rys. 2), a który można obliczyć według następującej formuly (INGALDI M., JAGUSIAK-KOCIK M., ZGAIBA A. 2013):

$$
\begin{aligned}
& Y=\mid \text { mocne strony }|-| \text { słabe strony } \mid \\
& X=\mid \text { szanse }|-| \text { zagrożenia } \mid
\end{aligned}
$$

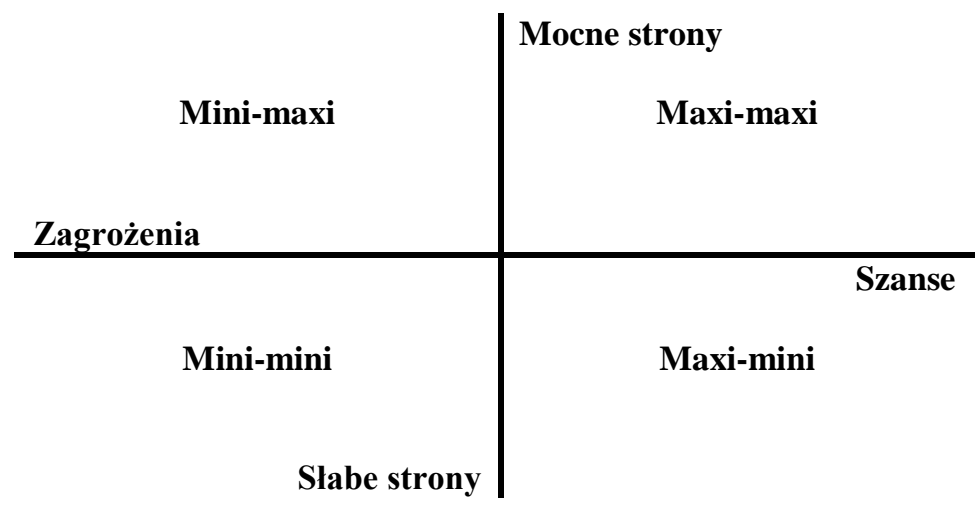

Rys. 2. Strategie wedlug analizy SWOT

Źródło: opracowanie własne na podstawie InGALDI M., JAGUSIAK-KociK M., ZGAIBA A. 2013. 


\section{Charakterystyka badanego przedsiębiorstwa}

Badanie przeprowadzono w wybranym przedsiębiorstwie poligraficznym, które znajduje się na terenie Częstochowy. Jest to małe, prywatne przedsiębiorstwo, które funkcjonuje na rynku od połowy lat dziewięćdziesiątych. Zyskało renomę na rynku lokalnym i polskim, ma swoich stałych klientów.

Każde przedsiębiorstwo, aby cieszyć się dobrą pozycja na rynku, stara się produkować swoje wyroby tak, aby mogły one w pełni zaspokoić potrzeby klienta związane z jakością otrzymanego produktu. Drukarnia przez wiele lat udoskonalała swój proces produkcyjny inwestując w nowoczesne urządzenia do druku i wysokiej jakości papier.

Drukarnia oferuje swoim klientom druk dziełowy, prasowy oraz akcydensowy. Druk dziełowy to wszelkiego rodzaju książki oraz broszury. Każdy druk dziełowy powstaje podczas procesów łączenia wkładu z okładką. Druk prasowy jest technologią, podczas której powstaje gazeta i czasopismo. Natomiast podczas drukowania akcydensowego powstają różnego rodzaju opakowania, ulotki informacyjne, katalogi itp.

Broszury drukowane w przedsiębiorstwie są małymi wyrobami poligraficznymi, liczącymi średnio 6 stron. W zależności od indywidualnego zamówienia okładki broszur powlekane są folą podczas laminowania, a ich format waha się w przedziałach od A6 do A4.

Współpracując z zarządem miasta drukarnia zajmuje się drukiem dziennika lokalnego. Gazeta drukowana jest na arkuszu o formacie A2, który zostaje zagięty w pół i tworzy dwie kartki. Materiałem stosowanym do produkcji gazety jest papier uzyskiwany z makulatury.

Drukarnia od kilku lat ściśle wykonuje zlecenia powierzone jej przez jeden z krakowskich banków. Zajmuje się drukowaniem adresu banku oraz jego logo na kopertach wysyłanych do klientów.

Przedsiębiorstwo, chcąc osiągnąć jak największe zyski, zaczęło zajmować się wydrukiem opakowań. Poswatają one na podłożu zwanym tekturą i są w odpowiednich miejscach zaginane, aby stworzyć kształt zgodny z zamówieniem klienta.

Drukarnia oferuje klientom druk nisko i wielkoformatowy. Swoje wyroby drukuje na arkuszach o wymiarach: A7 (74 x $105 \mathrm{~mm})$, A6 (105 x $148 \mathrm{~mm})$, A5 (148 x $210 \mathrm{~mm})$, A4 $(210 \times 297 \mathrm{~mm})$, A3 (297 x $420 \mathrm{~mm})$, A2 (420 x $594 \mathrm{~mm})$, A1 (594 x $841 \mathrm{~mm}$ ).

Przedsiębiorstwo w sowiej ofercie posiada również szeroki asortyment papieru wykorzystywanego do druku. Najpowszechniejszym rodzajem papieru stosowanym 
w drukarni jest papier offsetowy o gramaturze $80 \mathrm{~g} / \mathrm{m}^{2}$ oraz $90 \mathrm{~g} / \mathrm{m}^{2}$. Do produkcji ulotek i broszur stosuje się papier obustronnie powlekany $150 \mathrm{~g} / \mathrm{m}^{2}$ oraz $200 \mathrm{~g} / \mathrm{m}^{2}$.

\section{Wyniki}

W Tabelach 1 - 4 przedstawiono zestawienie poszczególnych grup czynników, które moją wpływ na pozycję strategiczną badanego przedsiębiorstwa poligraficznego.

Tabela 1. Klasyfikacja mocnych stron badanego przedsiębiorstwa

\begin{tabular}{|l|l|l|l|l|}
\hline Lp & Element & Waga & Ocena & Iloczyn \\
\hline S1 & Wysoki poziom umiejętności pracowników & 0,05 & 6 & 0,3 \\
\hline S2 & Jakość drukowanych produktów na wysokim poziomie & 0,1 & 8 & 0,8 \\
\hline S3 & Konkurencyjne ceny oferowanych produktów & 0,05 & 4 & 0,2 \\
\hline S4 & Szybka realizacja zamówień & 0,05 & 7 & 0,35 \\
\hline S5 & Terminowa realizacja zamówień & 0,15 & 6 & 0,9 \\
\hline S6 & Bogaty i nowoczesny park maszynowy & 0,05 & 7 & 0,35 \\
\hline S7 & Długoletnie doświadczenie & 0,05 & 6 & 0,3 \\
\hline S8 & Szeroki asortyment & 0,1 & 8 & 0,8 \\
\hline S9 & Nowoczesne wzornictwo & 0,15 & 8 & 1,2 \\
\hline S10 & Elastyczność produkcji & 0,15 & 7 & 1,05 \\
\hline S11 & Stali kontrahenci & 0,1 & 5 & 0,5 \\
\hline \multicolumn{4}{|c|}{ Srednia ważona } & 6,75 \\
\hline
\end{tabular}

Źródło: opracowanie własne

Tabela 2. Klasyfikacja słabych stron badanego przedsiębiorstwa

\begin{tabular}{|c|c|c|c|c|}
\hline Lp & Element & Waga & Ocena & Iloczyn \\
\hline W1 & Kosztowne przeglądy maszyn i urządzeń & 0,1 & 4 & 0,4 \\
\hline $\mathrm{W} 2$ & Wydłużony okres rozliczeń z klientami & 0,15 & 3 & 0,45 \\
\hline W3 & Niewielkie opóźnienia w dostawach & 0,05 & 4 & 0,2 \\
\hline $\mathrm{W} 4$ & Niewielka ilość klientów hurtowych & 0,1 & 7 & 0,7 \\
\hline W5 & Większość zamówień niestandardowych & 0,1 & 4 & 0,4 \\
\hline W6 & Słabo rozwinięty dział marketingu firmy & 0,1 & 5 & 0,5 \\
\hline W7 & Mała rozpoznawalność przedsiębiorstwa & 0,2 & 5 & 1 \\
\hline W8 & Słaba reklama & 0,2 & 6 & 1,2 \\
\hline \multicolumn{4}{|c|}{ Średnia ważona } & 4.85 \\
\hline
\end{tabular}

Źródło: opracowanie własne 
Tabela 3. Klasyfikacja szans badanego przedsiębiorstwa

\begin{tabular}{|l|l|r|r|r|}
\hline Lp & Element & Waga & Ocena & Iloczyn \\
\hline O1 & Możliwość poszerzenia gamy oferowanych produktów & 0,4 & 7 & 2,8 \\
\hline O2 & Umożliwienie pracownikom poszerzania kwalifikacji & 0,2 & 6 & 1,2 \\
\hline O3 & Rozwój technologii drukarskich & 0,2 & 3 & 0,6 \\
\hline O4 & Możliwość promocji w Internecie & 0,2 & 8 & 1,6 \\
\hline \multicolumn{2}{|c|}{ Średnia ważona } & 6,2 \\
\hline
\end{tabular}

Źródło: opracowanie własne

Tabela 4. Klasyfikacja zagrożeń badanego przedsiębiorstwa

\begin{tabular}{|c|l|r|r|r|}
\hline Lp & Element & Waga & Ocena & Iloczyn \\
\hline T1 & Pojawienie się na rynku ebooków & 0,3 & 7 & 2,1 \\
\hline T2 & $\begin{array}{l}\text { Oprogramowanie komputerowe i komórkowe używane } \\
\text { przez potencjalnych klientów }\end{array}$ & 0,3 & 6 & 1,8 \\
\hline T3 & Wysoka konkurencyjność branży poligraficznej & 0,2 & 5 & 1 \\
\hline T4 & Łączenie oraz porozumienia aktualnych konkurentów & 0,1 & 4 & 0,4 \\
\hline T5 & Tworzenie nowych firm działających w branży & 0,1 & 4 & 0,4 \\
\hline \multicolumn{2}{|l|}{ Średnia ważona } & 5,7 \\
\hline
\end{tabular}

Źródło: opracowanie własne

Na podstawie Tabel 1 - 4 wyznaczono punkt, który odnosi się do pozycji strategicznej badanego przedsiębiorstwa poligraficznego, a który pozwoli wskazać kierunki przyszłych jego planów strategicznych (rys. 3). Punkt ten wyznaczono według wzorów (1) i (2) w następujący sposób:

$$
\begin{aligned}
& Y=\mid \text { mocne strony }|-| \text { słabe strony } \mid=6,75-4,85=1,90 \\
& X=\mid \text { szanse }|-| \text { zagrożenia } \mid=6,2-5,7=0,5
\end{aligned}
$$

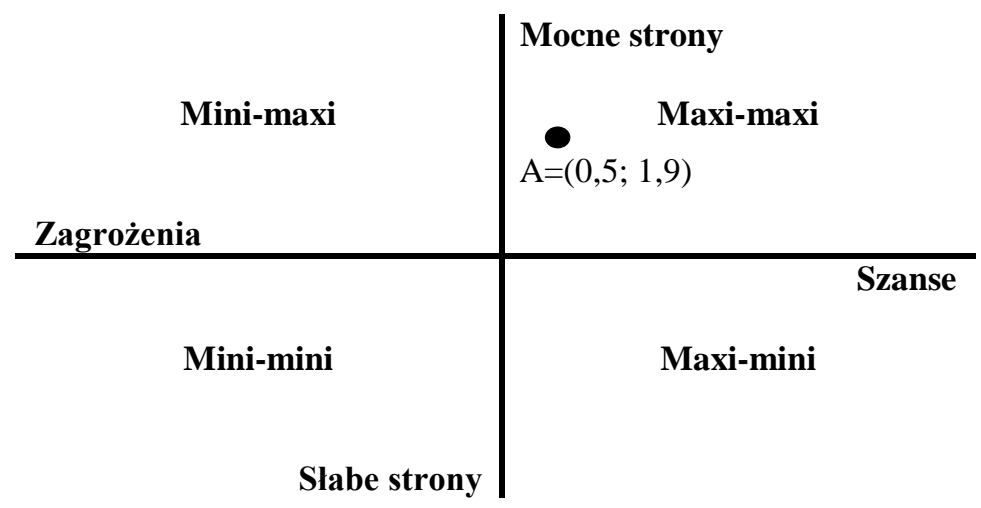

\section{Rysunek 3. Pozycja strategiczna badanego przedsiębiorstwa poligraficznego}

Źródło: opracowanie własne 
Analizując wyniki analizy SWOT można stwierdzić, że przedsiębiorstwo ma więcej mocnych stron, niż wad, zaś w jego otoczeniu znajduje się więcej szans niż zagrożeń, czyli badane przedsiębiorstwo znajduje się w pierwszej ćwiartce układu kartezjańskiego, co oznacza strategię maxi-maxi, czyli strategię agresywną. W tej strategii przedsiębiorstwo powinno wykorzystać swoje mocne strony w celu maksymalizacji szans płynących z jego otoczenia. Sukces firmy zależy bowiem od jej wnętrza i potencjału.

Do takiego wyniku analizy przyczyniło się wiele czynników. Wśród mocnych stron przedsiębiorstwa na szczególną uwagę zasługują: jakość drukowanych produktów na wysokim poziomie, szeroki asortyment oraz nowoczesne wzornictwo. Wszystkie te czynniki oceniono na poziomie 8 , co oznacza, że miały one duży wpływ na poziom mocnych stron badanego przedsiębiorstwa. Klienci chwalą jakość drukowanych produktów, co świadczy o wysokiej jakości druku. Dzięki temu klienci ci będą wracać do przedsiębiorstwa i zamawiać kolejny druk produktów. Chwalą oni również szeroki asortyment i nowoczesne wzornictwo. Jest to ważne, zwłaszcza że klienci mają coraz nowsze i bardziej skomplikowane pomysły, coraz większe wymagania. Dzięki tym dwóm czynnikom badane przedsiębiorstwo drukarskiej może spełnić te wymagania. Najniżej $w$ tej grupie oceniono konkurencyjne ceny oferowanych produktów (na poziomie 4). Może to spowodować, że klienci, którzy kierują się głównie ceną produktów, mogą skorzystać $\mathrm{z}$ oferty innych przedsiębiorstwa branży.

Wśród słabych stron dominowały niewielka ilość klientów hurtowych (ocena 7) oraz słaba reklama (ocena 6). Klienci hurtowi to klienci, którzy regularnie zamawiają druk określonej ilości produktów, co wpływa na stały zysk. Natomiast słaba reklama powoduje, że wielu klientów, którzy korzystają z oferty branży drukarskiej, nie wie, że badana firma istnieje i jaką ma ofertę. Najniżej oceniono wydłużony okres rozliczeń z klientami (ocena 3). Oznacza to, że firma ma niewielkie problemy z tym czynnikiem, ale nie są one aż tak poważne.

W przypadku badanego przedsiębiorstwa drukarskiego nie odnotowano wielu szans, jednak zostały one oceniono dość wysoko. Najważniejszą szansą dla przedsiębiorstwa jest możliwość promocji w Internecie (ocena 8). Może ona pomóc w poprawie reklamy i promocji badanego przedsiębiorstwa. Z Internetu korzysta wiele osób, wielu potencjalnych klientów, dlatego łatwo dotrzeć do szerszej grupy osób. Kolejną szansą jest możliwość poszerzenia gamy oferowanych produktów (ocena 7). Dzięki elastyczności produkcji przedsiębiorstwo jest w stanie dostosować się do ciągle nowych pomysłów i zamówień klientów, a następnie wprowadzić takie zamówienia do swojej oferty. Rozwój technologii drukarskich został oceniony nisko (ocena 3), gdyż istniejące na rynku technologie są nowoczesne, ale również wyposażenie 
przedsiębiorstwa zostało oceniono $\mathrm{w}$ mocnych stronach wysoko. Dlatego jest to ważny element dla przedsiębiorstwa, ale nie będzie miał aż tak dużego wpływu jak pozostałe szanse.

Wśród słabych stron najwyżej oceniono pojawienie się na rynku ebooków (ocena 7) oraz oprogramowanie komputerowe i komórkowe używane przez potencjalnych klientów (ocena 6). Ebooki to elektroniczne formy książek, które zamiast czytać, klient słucha w dowolnym miejscu. Jest duża grupa klientów, która woli taką formę publikacji. Wiele osób posiada także odpowiednio wyposażone komputery czy telefony, które pozwalają na druk wielu rzeczy, które jeszcze niedawno zamawiano w drukarniach.

Proponowane elementy strategii agresywnej przedstawiono w tabeli 5.

\section{Podsumowanie}

W artykule przeprowadzono analizę SWOT dla wybranego przedsiębiorstwa poligraficznego. Analiza ta pozwoliła wskazać jego pozycję strategiczną oraz kierunki przyszłym działań, które powinny być zawarte w strategii przedsiębiorstwa. Badanie przeprowadzono $\mathrm{w}$ wybranym przedsiębiorstwie poligraficznym ze względu na duża zainteresowanie takimi wyrobami oraz pomijanie branży $\mathrm{w}$ badaniach. Jest to niewielkie przedsiębiorstwo, które mieści się na terenie Częstochowy, a które ma już swoją renomę.

Jako najważniejsze mocne strony badanego przedsiębiorstwa wskazano jakość drukowanych produktów na wysokim poziomie, szeroki asortyment oraz nowoczesne wzornictwo, natomiast wśród słabych stron dominowały niewielka ilość klientów hurtowych oraz słaba reklama. Jako najważniejsze możliwości wskazano możliwość promocji w Internecie, a zagrożenie pojawienie się na rynku ebooków oraz oprogramowanie komputerowe i komórkowe używane przez potencjalnych klientów.

Dzięki przeprowadzonej analizie pokazano, że sugerowaną strategią dla badanego przedsiębiorstwa jest strategia agresywna. Badane przedsiębiorstwo powinno wykorzystać pojawiające się $\mathrm{w}$ jego środowisku możliwości oraz swoje mocne strony. 
Tabela 5. Elementy proponowanej strategii

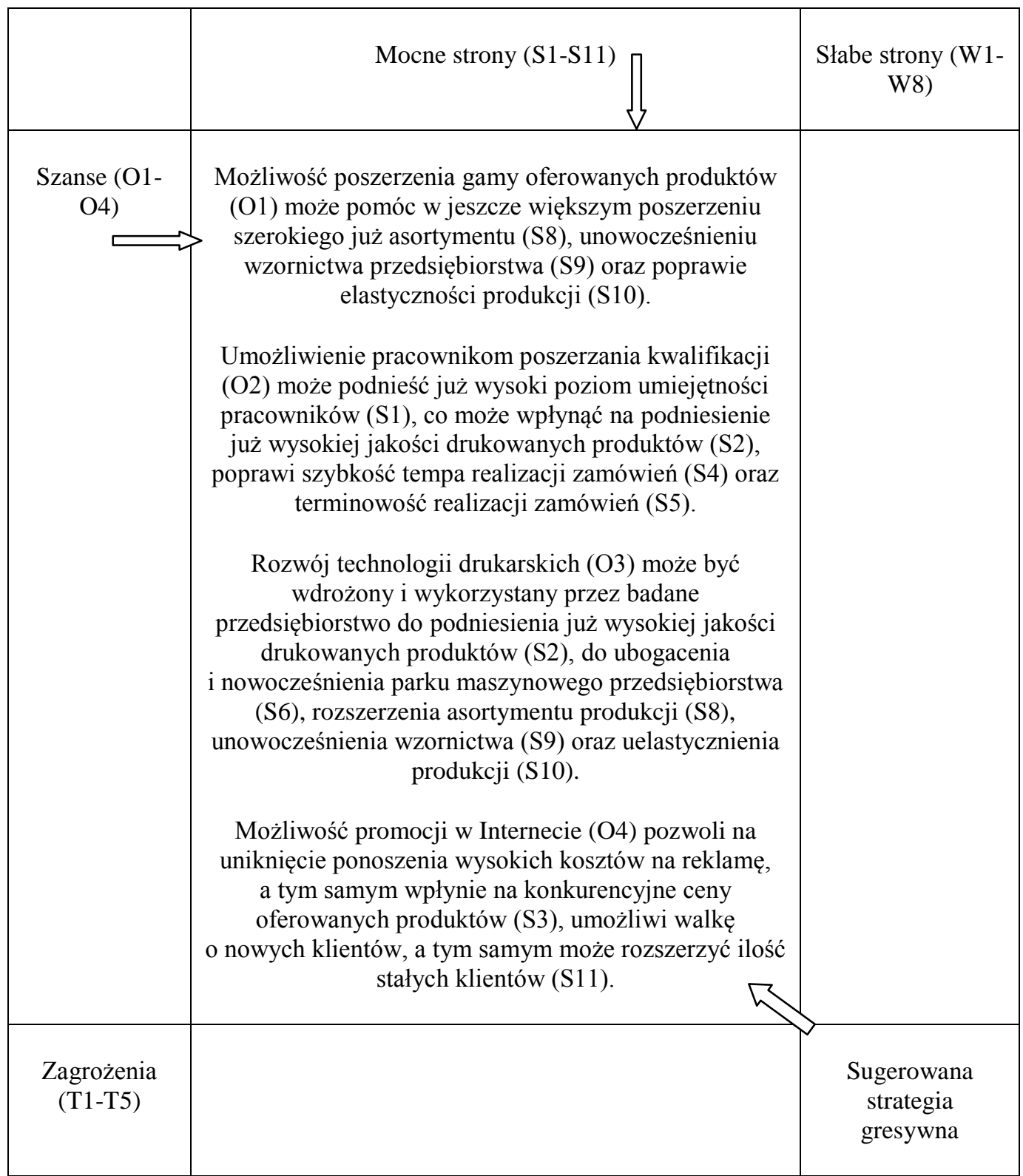

Źródło: opracowanie własne 


\section{Bibliografia}

1. Chandler A. A., Jr. Strategy and Structure: Chapters in the History of American Industrial Enterprise. MA, The MIT Press, Cambridge, 1962.

2. GIERSZEWSKa G., RomANOWSKA M. Analiza strategiczna przedsiębiorstwa. Warszawa, PWE, Warszawa, 2002.

3. GORANCZEWSKI B., PUCIATO D. SWOT analysis in the formulation of tourism development strategies for destinations. Tourism, 2010, 20/2, s. 45-53.

4. Ingaldi M., JAGUSIAK-KocIK M., ZGAIBA A. (2013). Use of SWOT analysis for determining a strategic position of the dairy company. [w:] Toyotarity. Evoluation and Processes'/Products' Improvement. Red. Borkowski S., Popa M., Sava ${ }^{\circ}$ Kitap ve Yayınevi, Ankara, Türkiye, 2013, s. 8-17.

5. KadŁubeK M., Ingaldi M. Evaluation of the Strategic Position of the Company of the Metallurgical Industry by SWOT Analysis. [w:] METAL 2016. 25th Anniversary International Conference on Metallurgy and Materials, Tanger, Brno, 2016, s. 18441850 .

6. Kotus M., Holota T., PAUličEK T., Petrík M., Sklenár M. Quality and reliability of manufacturing process in automation of die-casting. Advanced Materials Research, Germany, vol. 801, special iss., 2013, s. 103-107.

7. Learned E. P., Christensen C. P., Andrews K. R., Guth W. D. Business Policy: Text and Cases. IL. Richard D. Irwin, Homewood, 1965.

8. LESTYÁNSZKA ŠKŮRKOVÁ K., KUDiČOVÁ J. The process capability study of pressing process for force closed. Vedecké práce MtF STU v Bratislave so sídlom v Trnave, 2011, vol. 19, Nr. 30, s. 51-57.

9. MintzBerg H. The Structuring of Organization. Prentice-Hall, Inc., Englewood Cliffs, 1979.

10. Printing Industry \& Printed Packaging Market in Poland. SIXTH EDITION, Polskie Bractwo Kawalerów Gutenberga, Warszawa, 2016.

11. PRUSAK R, KARDAS E., SkUZA Z. Analiza strategiczna działalności przedsiębiorstwa przewozowego. Logistyka, 2012, $\mathrm{Nr}$ 6, s. 236 - 238.

12. PUSTĚJOVSKÁ P., JuRSOVÁ S., BROŽOVÁ S., PIVKO M. Injection of brown coal tar in relation with significant parameters of blast furnace. Materiali in Tehnologije, 2012, vol. 46, Nr 6, s. 673-676.

13. SKOWRON-GRABOWSKA B., KADŁUBEK M. Kierunki formułowania strategii logistycznych $w$ przedsiębiorstwach międzynarodowych. [w:] Zeszyty Naukowe Uniwersytetu Ekonomicznego w Poznaniu, 2010, Nr. 157, s. 143-153.

14. Strategy skills. Team FME, 2013, http://www.free-management-ebooks.com/ 